\title{
THE CONCEPT OF HUMAN DIMENSION IN THE CONTEXT OF ANTHROPOLOGICAL DISCOURSE OF HUMANISTIC MANAGEMENT
}

\author{
Valentina Voronkova, Marina Maksimenyuk, Vitalina Nikitenko \\ Zaporizhzhya State Engineering Academy, Zaporizhzhya, Ukraine
}

\begin{abstract}
ANNOTATION
This author's practice is part of performing the tasks of SRW of the Ministry of Education and Science "Formation of mechanisms of civilization development of modern socium in a global dimension" (0111U010481), which will be used for preparing management regional development programs, particularly in determining the ways and trends of social development under the conditions of globalization, which allows to expand the means and methods of implementing economic, political and social reforms in the country to comply with general civilization standards. The main provisions of scientific results form the theoretical and methodological basis of studying modern anthropological dimensions of the human being in European philosophy.
\end{abstract}

Keywords: human dimension, anthropological discourse, humanistic management.

\section{INTRODUCTION}

Revalance of theme. Human dimension comes from the fact that reserves of humanistic development of economics, politics and culture are to be found in human himself/herself, the development of his/her consciousness and spiritual capital. Without the development of anthropological capital, further development and improvement of the society become impossible. The most important resource of human dimension is intensification of anthropological capital and human existence. Anthropological principles of human dimension are terms of saving human, natural, social and political resources. In its substantive characteristics, the concept of human dimension includes theoretical and conceptual grounding of "typical" tasks of humanization of politics, economy, ecology, social policy, science, education and culture.

The acquired knowledge may be useful for solving anthropological problems of humanistic management.

Problem situation. In the context of philosophical and anthropological dimensions, emphasis is shifted to human ontology, in which doctrine of the meaning of human life and the possibilities of its comprehension, in particular by examining the conflict of human world-attitude and self-creation is central. Through the anthropological principle, an attempt to explain the man himself and the surrounding world, comprehend the man and the surrounding world, understand the man as a unique phenomenon, as the creator of history and culture is made. Fundamental questions of philosophical and anthropological discourse - the attitude of man to the world and the world to man: What is the world we live in? What is person's place in this world? What is the person himself/herself and what is the nature of his/her consciousness?

Research problems. Philosophical and anthropological aspect of humanistic management is fundamental in European philosophy, so we turn to the reception of man in the projection of 
anthropological dimensions of human being, which are reduced to the following trends, existing in the world today.

The aim of research was to analyze the concept of the human dimension as the anthropological basis of humanistic management tasks.

The main conclusion: To fulfil all tasks of the concept of human dimension as the anthropological basis of humanistic management, it is necessary to form the elite of humanitarian managers, exercise social and humanitarian policy by forming the key objectives of humanitarian management activity in human dimensional direction: national (semiotic); personal growth and activity self-determination (anthropological); spatial; strategic thinking and political action.

Human dimension comes from the fact that reserves of humanistic development of economics, politics and culture are to be found in human himself/herself, the development of his/her consciousness and spiritual capital. Without the development of anthropological capital, further development and improvement of the society become impossible. The most important resource of human dimension appears to be intensification of anthropological capital and human existence. Anthropological principles of human dimension are terms of saving human, natural, social and political resources. In its substantive characteristics, the concept of human dimension includes theoretical and conceptual grounding of "typical" tasks of humanization of politics, economy, ecology, social policy, science, education and culture. The acquired knowledge may be useful for solving anthropological problems of humanistic management.

\section{RESEARCH METHODS}

Theoretical substantiation. Scientific literature analysis was performed in order to define particularly in determining the ways and trends of social development in the conditions of globalization, which allows expanding the means and methods of implementing economic, political and social reforms in the country to comply with general civilization standards. The main provisions of scientific results form the theoretical and methodological basis of studying modern anthropological dimensions of the human being in European philosophy. Methodological and general scientific significance of receptions of anthropological dimensions of human existence in European philosophy creates conditions for forming a new format of European philosophy, which can be defined as a system of worldviews, based on the true foundations of human freedom. The study analyzed the philosophy investigators consider. The human dimension of the anthropological discourse in the context topic analyzed A. Boholm (2003), H. Hazan (2009), V. H. Tabachkovs'kyi et al. (2005); L. H. Gerstein et al. (2007); E. Balibar (2012). O. Yu. Golovina (2016), V. G. Voronkova (Воронкова, 2010), V. O. Nikitenko (Нікітенко, 2013), M. J. Maksimeniuk (Максименюк, 2015) and other authors.

Research methods. The study employed theoretical analysis, carried out as comprehensive as possible in the selected area of the research results obtained, defining the concepts used in the work, providing structure. Theoretical study material was summarized using the synthesis method. 


\section{RESULTS AND DISCUSSION}

\section{Definition of unsolved aspects of the general problem the paper deals with}

The article defines three trends in the attitude of a person towards the world of social existence. Trend one: a) the attitude of a person to the world of social life shows the attitude of a person to socium and is characterized as specific self-creation of a person, self-realization in this world, and in this sense - the dominance of a person as "the measure of all things" (Protagoras); b) the person acts not so much as the creator of the society, not so much as a substance that is embodied in a society that holds to a certain extent the existence and functioning of society in this sense, so it conforms to its needs and laws, and therefore acts as a force, in some respects conformable to society; c) the person acts as creator of his/her own sociomicrocosm of everyday life. These three trends - the attitude of a person to the world of social existence - lead to forming a certain triad: 1) the person within the first set of relations dominates the world;2) within the second - conforms to it; 3) within the third - shows a peculiar synthesis - the creation of the world by the person and, depending on it, conformity to it. All these three groups of interdependencies of relations appear together, concurrently and are inseparable from each other; they form a single trend, based on the law of negation. In the context of this diversity of relationships, moment of integral attitude of man to the world of his social being is formed, and this integrity is inseparable and makes the connection of all components inseparable. A man both dominates the world of his social life, and conforms to it; therefore, it is basically impossible to break this inconsistency of human relationships (Ввайнхардт, Андрюкайтене, 2013).

Trend two can be described as a trend of isolating phenomenon of a person. Thus, at the first level of relations, human nature in the abstract-substantial sense is presented weekly, vaguely in the overall substantiality of man. In the second system of relations, it appears more clearly in the massfunctional existence, in its being reduced to sociality, its serving role. However, at the third level of relations, human nature reveals most vividly, in its directly-pure form, suggesting that human nature at different levels of relations appears from different sides, which are inextricably interconnected and create the whole integrity of both exchange, and distribution of socially significant work, through the states of the loss of subjectivity, emergence of senses of independence and depression. A person relative to the world acts as a holistic and multifaceted subject, whose multidimensionality is an extremely difficult problem.

Anthropological analysis of the levels of man allows to show the complexity of this versatility, abundance of differences, even contradictions of approaches to analyzing man as a complex social being, despite the great diversity of approaches to man. Multidimensionality of a person has a lot of individual dimensions since a person has cosmic, physical, biological, social, psychological and cultural components. The person is a historical and creative being, who, in the process of reformative activity, transforms nature, society, himself/herself, developing his/her physical and spiritual potentials. Creative, reformative human activity indicates highly-complex, multi-dimensional system. In general, multi-dimensional person possesses the creative thinking and tries to actualize himself/herself as a personality. Modern anthropological space on a global scale in certain tendencies becomes harmful to the personality, humanism, spiritual values; it is a narrative structure, hyper 
reality because it contains the same impersonal particle «man». That is why modern person has become not the goal, but a means to achieve (by power - formal and informal - structures) any purposes (political, ideological, economic, and philosophical).

Receptions of a person in the projection of anthropological dimensions of human existence in European philosophy deepen relations of humanizing the surrounding world of nature and society from the standpoint of developing human needs. This means that the criterion of social progress and its ultimate goal is the human personality, the possibility and the prospect of its comprehensive development and its universalization within culture, socium and nature. Problems of modern secular humanism in fact combine these two vectors of social sciences and the humanities. It integrates political and historical aspects of the analysis, giving a truly global perspective to humanism (Воронкова, 2010).

\section{Methodological and general scientific significance}

Methodological and general scientific significance of receptions of anthropological dimensions of human existence in European philosophy creates conditions for forming a new format of European philosophy, which can be defined as a system of worldviews, based on the true foundations of human freedom. Receptions of anthropological dimensions of human existence necessitate overcoming entropic processes that interpret the conditions of creating human society, in which imperatives of human society must be implemented, and the conditions for forming a strategy of social progress must be created.

Analysis of the patterns of forming the anthropological paradigm of human dimension as the basis of European philosophy is oriented toward humanistic factor: a) increasing the level of economic development in the context of building a social-democratic state with a mixed economy; b) development of the constitutional state; c) the systematic improvement of legislation and forms of its presentation; d) formation of civil society and its institutions; e) formation and development of social responsibility in the sphere of public administration. Anthropological doctrine deduces its understanding of man and the surrounding reality from the human being and through it.

Essence of human dimension as an anthropological paradigm of humanistic management focuses on the fact that man is not only an economic or political member of society, but also a sociocultural phenomenon that incorporates all the rational, cognitive-creative, cognitiveinformative, which intertwine with emotional-volitional, traditionalist, national-historical, nationalpsychological elements. But being a reality, which takes certain place in the given space-time limits, does not make the individual historical. Democratic transformations of modern Ukrainian society determine the social formation of such values of anthropology, which are caused by specific historical circumstances. It is the question of forming such type of welfare state, which would focus on a man, his high social purpose, the orientation of the welfare state on the man, his well-being, happiness. In addition, there is no other way to make politics really humane and human, to combine it with morality and man. Philosophical anthropology covers the full range of issues that make up the essence of human problem in the coordinates of the universal laws of life and universal principles of human activity. The humanistic basis of human dimension as an anthropological paradigm of European 
philosophy is giving the humanistic connotation to social life, focusing on realizing human interests and values, when each man discovers the way to personal substantiality.

Human dimension as an anthropological paradigm of European philosophy explores the anthropological bases of economic, political and social spheres; interprets the conditions of creating humane society, in which imperatives of a just society must be implemented, notions such as "humane society", "humane relationships", "humane person", "humanistic management" must be rehabilitated. In anthropological paradigm as a matrix of anthropocentrism, a total approach to the study of man as socio-cultural being is used, the focus is placed on forming a society that is based on the ideals of justice, solidarity, social consensus, based on anthropological mode of man, i.e. forming the anthropological foundations of the welfare state, stable social development, overcoming lag of Ukraine from highly developed countries.

The object of human dimension as an anthropological paradigm of European anthropological philosophy is a set of ideas, principles, concepts of humanism that constitute a paradigm of political anthropology, accumulated by Western political and economic doctrines that ensure the regulation of relations in sociums with a focus on anthropological paradigm of culture and management. It is the anthropological paradigm as a paradigm of European philosophy that is seen as a culture, which is able to support the practical-political implementation of general democratic values, which would contribute to the development of individual completeness and integrity of the personality. It is primarily about a constitutive significance of the human personality and his experience to find new forms of social, political and religious relations, in which man is considered as the limiting form of realizing the idea of civil society, dialogue (polyphony of voices), possibility to initiate transformative processes in a changing and contradictory political life. These problems become especially relevant in view of the fact that as a result of human insecurity in conditions of crisis socium, overcoming the destruction of the personality, non-self-identity, non-integrity of the personality, dissociation of consciousness, man becomes alienated from the whole world of society, nature, himself. After all, man enters a social world not as an abstract being, but as a concrete social integrity, hence political anthropology should form an environment that would be worthy of a complete image of personality, and therefore civilized lifestyle.

Receptions of human dimension as anthropological paradigm of European philosophy are based on domestic and foreign experience in theory and practice, science, culture and education, includes the principles of humanism as a system of beliefs that define the disclosure of human capabilities as a criterion for evaluating the effectiveness of the state and maturity of social institutions, and the inherent right of everyone to free development of personality and realization of all his capabilities. Post-industrial era as the sociocultural context of modern activity paradigm creates new sociocultural trends, associated with forming a new paradigm of human dimensional foundations of management. Human dimension management is based on the following principles: 1) the principle of anthropological reduction as explanation of objective formations of politics, government and culture through their relatedness to man; 2) the principle of authority as a holistic perception of human nature, based on created objective forms of culture; principle of anthropological interpretation of certain phenomena of human life, based on human dimension, anthropologism, humanism; 
3) anthropological principles, based on "man as the measure of all things"; 4) development and the fullest use of the national cultural heritage in the multifaceted relations with other national cultures, openness to cultural interaction to ensure proper place for Ukraine in the European and global humanitarian space; 5) interaction between the state and civil society, business and government to create the necessary social and economic conditions for improving the quality of life, comprehensive harmonious development of man, protection of his rights and freedoms (Максименюк, 2015).

Reception of human dimension as an anthropological paradigm of European philosophy is the basis of the anthropological paradigm of management, it is a human dimension of economics and politics, economic ethics, dialogue and tolerance as imperatives of human relations, social pragmatism and focus on the real needs of "earthly man", which provide a broad social base, possibility to survive in a crisis society. The essential feature of anthropological principles of management is that they focus on combining individual and group valuable institutions, social, national and general civilizational interests. The civilization of the XXI century with its vast technological progress and equally impressive tragedies, on one hand, has created opportunities for implementing projects of true human dimension, and on the other hand has caused deepening effect of crisis factors, which "totally" threaten humanity. As a result of these processes, mankind faces a choice, the crucial role of which belongs to human dimension and human dimensional European values. In these conditions, following anthropological standards should become the main criterion of public management. In this regard, it should be noted that in order to purposefully solve strategic programs of human development, developed by the government, they are aimed at implementing the concepts of human dimensional development. It is post-industrial era that underdetermines evolution of humanitarian sociocultural processes, allows to fix the substitution of technicist society paradigm by sociocultural development paradigm, directed to forming "symbolic man", created by the information epoch (Castells); forming post-industrial humanitarian market; inquiring for searching new meanings and forming new types of activity and professionalization systems, oriented on humanitarian production (human production).

Reception of human dimension as an anthropological paradigm of European philosophy is a new type of management activities, aimed at achieving positive qualitative changes in all spheres of society by means of humanism, anthropocentrism, use of humanitarian resources and technologies. The human dimension is based on the concepts of communication, professional self-determination, cultural and symbolic capital, cultural policy. The human dimension is conceptualized as a sociocultural and anthropological phenomenon, introduced in the context of post-industrial scale of values, based on the activity theories of both the individual, and the government. Human centrism as type of politics is formed on the basis of the system model, which includes the evaluative, descriptive and instrumental clusters: 1) evaluative cluster includes the values of strategic thinking and cooperation, effective communication and productive reflection, responsibility and development, improving quality of life; 2) descriptive cluster is defined by objects of anthropological dimension of public management, such as symbols, institutions, communities, territories, spaces, sociocultural processes, and includes professional communities of humanitarian managers as subjects of sociocultural space; 3 ) instrumental cluster forms the types of resources, such as symbolic (the space 
of communication and language of profession), competence (communicativeness, reflexivity, creativity and projectivity) ( Нікітенко, 2013).

The anthropological principles of human dimension of European philosophy are based on the possibility of forming the elements of universal culture, which are determined by: 1) the needs of social practice that necessitate reflection of phenomenon of humanistic management in a global transformation; 2) the need for a comprehensive understanding of the nature, meaning, functions, development areas of humanistic management in the socialization of the economy by features of humanistic management as an integrated social system, determining the place and role of the main sub-structures of humanistic management; 3) the importance of effective management of economic and social systems in transitive societies, maintaining political, social, economic and cultural stability, associated with effective mechanisms of ensuring humanistic management; 4) the need to provide all levels of management mechanism with humanistic scientific knowledge about the nature and character of the interrelation of objective conditions of ensuring human dimensional management in organizations, peculiarities of its functioning in conditions of transformation processes (transitive, transient, and modernization). The main area of anthropological development of Ukraine is the purposeful formation of a new quality of life, which consists in creating conditions for proper realization of opportunities of each person and guarantee of a decent living standard.

In modern conditions of development of the state, for elaborating and implementing human dimension as the basis of management practice, it is necessary to: 1) analyze the objective need for developing humanization of the socium as an integrated social and economic social system, in the context of which feedbacks work harmoniously; 2) identify "fundamental economic and managerial constants", which are stable basis of management system operation in the marketplace; 3 ) develop areas of optimizing the mechanism of effective assurance of humanistic management to prepare absolutely new managerial elite of the XXI century; 4) develop and implement socioantropological paradigm of human dimensional European humanistic management, based on self-organizational and system processes. Human dimension as humanistic principle of management is aimed at forming human dimensional European humanistic management as a management paradigm of the XXI century, which is a multi-paradigmatic sphere of knowledge, based on several independent paradigms that are determined by the following factors: 1) practical: humanistic management is a practical field of activity that is related to solving practical problems, arising in different spheres of society; 2) institutional: humanistic management is a set of institutions that conduct humanistic management activity; 3) activity: humanistic management is the activity, related to the state management; 4) regulatory and legal: humanistic management serves as a legal and regulatory system that governs the state management; 5) scientific: humanistic management is an area of scientific knowledge, which is implemented in the state activity; 6) system: humanistic management should be formed as a system that requires a system regulation and self-regulation; 7) instrumental: humanistic management is a set of instruments for state management and influence on society; 8) innovative: humanistic management serves as an important mechanism for implementing innovations and renewing all spheres of society; 9) liberal: humanistic management is a way of regulating the relations between subjects of politics, government, management, centred around the "man as the measure of all things". 


\section{CONCLUSIONS}

1. To fulfil all tasks of the concept of human dimension as the anthropological basis of humanistic management, it is necessary to form the elite of humanitarian managers, exercise social and humanitarian policy by forming the key objectives of humanitarian management activity in human dimensional direction: a) national (semiotic); b) personal growth and activity selfdetermination (anthropological); c) spatial; d) strategic thinking and political action.

2. Promote development of human dimensional outlook of humanitarian managers and development of human dimensional technologies, which are a set of scientifically grounded methods and special techniques of indirect impact on society through the management of social human behaviour.

3. Promote modernization of human dimensional European space of Ukraine, which requires establishing a modern human dimensional culture of public management; full integration of Ukraine into the information space; strengthening the Ukraine's presence in the global humanitarian space.

\section{REFERENCES}

1. Balibar, E. (2012). From philosophical anthropology to social ontology and back: What to do with Marx's sixth thesis on feuerbach? Postmodern Culture, 22 (3).

2. Boholm, A. (2003). The cultural nature of risk: Can there be an anthropology of uncertainty? Ethnos: Journal of Anthropology, 68 (2), 159-178.

3. Gerstein, L. H., Rountree, C., Ordonez, A. (2007). An anthropological perspective on multicultural counselling. Counselling Psychology Quarterly, 20 (4), 375-400.

4. Golovina, O. Yu. (2016). The spiritual intelligence as an integrating factor of human consciousness. Вісник ХНПУ імені Г. С. Сковороди. Психологія, 53, 29-37.

5. Hazan, H. (2009). Essential others: anthropology and the return of the old savage", International Journal of Sociology and Social Policy, 29 (1/2), 60-72.

6. Tabachkovs'kyi, V. H., Bulatov, M. O., Liutyi, T. V., Khamitov, N. V. (2005). Man in civilization of the 21st century: Problem of freedom. Kyiv: Naukova dumka [in Ukrainian].

7. Ввайнхардт, Й. Р., Андрюкайтене, Р. М. (2013). Влияние типов организационной культуры на развитие корпоративной социальной ответственности. Проблемы экономики и менеджмента: научно-практический журнал (Ижевск), 12 (28), 62-75.

8. Воронкова, В. Г. (2010). Філософія глобалізації: соціоантропологічні, соціоекономічні та соціокультурні виміри. Запоріжжя: Видавництво ЗДІА.

9. Максименюк, М. Ю. (2015). Організації як об’єкт публічного адміністрування: теоретико-методологічні виміри. Гуманітарний вісник Запорізької державної інженерної академії: збірник наукових праџь (Гол. ред. д. філософ. н. В. Г. Воронкова), випуск 63, (сс. 99116). Запоріжжя: ЗДІА. 
10. Нікітенко, В. О. (2013). Загальнолюдські цінності як геоцінності планетарного масштабу. Гуманітарний вісник Запорізької державної інженерної академіӥ: збірник наукових праць (Гол. ред. д. філософ. н. В. Г. Воронкова), випуск 55, (сс. 131-138). Запоріжжя: ЗДІА.

\title{
THE CONCEPT OF OF HUMAN DIMENSION IN THE CONTEXT OF ANTHROPOLOGICAL DISCOURSE OF HUMANISTIC MANAGEMENT
}

\author{
Valentina Voronkova, Marina Maksimenyuk, Vitalina Nikitenko \\ Zaporizhzhya State Engineering Academy, Zaporizhzhya, Ukraine
}

\begin{abstract}
Grounding of research. Human dimension comes from the fact that reserves of humanistic development of economics, politics and culture are to be found in man himself, the development of his consciousness and spiritual capital. Without the development of anthropological capital, further development and improvement of society become impossible. The most important resource of human dimension appears intensification of anthropological capital and human existence. Anthropological principles of human dimension are terms of saving human, natural, social and political resources. In its substantive characteristics, concept of human dimension includes theoretical and conceptual grounding of "typical" tasks of humanization of politics, economy, ecology, social policy, science, education and culture.
\end{abstract}

Problem situation. In the context of philosophical and anthropological dimensions, emphasis is shifted to human ontology, in which doctrine of the meaning of human life and the possibilities of its comprehension, in particular by examining the conflict of human world-attitude and self-creation is central. Through the anthropological principle, an attempt to explain the man himself and the surrounding world, comprehend the man and the surrounding world, understand the man as a unique phenomenon, as the creator of history and culture is made. Fundamental questions of philosophical and anthropological discourse - the attitude of man to the world and the world to man: What is the world we live in? What is man's place in this world? What is the man himself and what is the nature of his consciousness?

Research problems. Philosophical and anthropological aspect of humanistic management is fundamental in European philosophy, so we turn to the reception of man in the projection of anthropological dimensions of human being, which are reduced to the following trends, existing in the world today.

The aim of research: analyse the concept of the human dimension as the anthropological basis of humanistic management tasks.

Conclusions. To fulfil all tasks of concept of human dimension as the anthropological basis of humanistic management, it is necessary to form the elite of humanitarian managers, exercise social and humanitarian policy by forming the key objectives of humanitarian management activity in human dimensional direction: a) national (semiotic); b) personal growth and activity self-determination (anthropological); c) spatial; d) strategic thinking and political action. Promote development of human dimensional outlook of humanitarian managers and development of human dimensional technologies, which are a set of scientifically grounded methods and special techniques of indirect impact on society through the management of social human behaviour. Promote modernization of human dimensional European space of Ukraine, which requires: establishing a modern human dimensional culture of public management; full integration of Ukraine into the information space; strengthening the Ukraine's presence in the global humanitarian space.

Keywords: human dimension, anthropological discourse, humanistic management. 